\title{
DEVELOPING INTERACTIVE MULTIMEDIA TO TEACH READING NARRATIVE TEXT USING ADOBE FLASH CS6
}

\author{
Sherli Oktaviyani, Regina Regina, Wardah Wardah. \\ English Education Study Program of Teacher Training and Education Faculty \\ Universitas Tanjungpura, Pontianak \\ Email: sherlioktaviyani@gmail.com
}

\begin{abstract}
This research aims to find out the target needs, learning needs and developed the appropriate reading interactive multimedia for the tenth-grade students of MAN 2 Pontianak. This is a Research and Development (R\&D) using ADDIE procedures. ADDIE stands for Analysis, Design, Develop, Implement, and Evaluate. The subjects of this research were the English teacher and the tenthgrade students of MAN 2 Pontianak. The data were collected through interviews, questionnaires, and expert judgments. The researcher used Adobe Flash CS6 to develop interactive multimedia. The result of the needs analysis showed that the students needed interesting materials, fun activities, and animation videos to support their learning English, especially in reading skills. Therefore, this study developed the topic of narrative text, which was implemented in interactive multimedia. This interactive multimedia consists of materials of the narrative text, narrative story, animation videos with subtitles, and quiz with four activities. This interactive multimedia focused on learning the correct pronunciation, vocabulary, grammar (past tense), and the text types of narrative text. Based on the result both from the teacher and the multimedia expert, it said that the interactive multimedia quality belongs to the "very good" category with $4.21<$ $X \leq 5$. It can be concluded that the interactive multimedia is effective and appropriate to implement in the class by the English teacher.
\end{abstract}

Keywords: Interactive Media, Narrative Text, Reading

\section{INTRODUCTION}

Due to the digital era, teaching and learning process should be supported by technology. Technology is used as the media for teachers to do innovation in the teaching-learning process. Teachers are expected to be creative, innovative, and have digital skills. Teachers should be aware of the student's needs in this digital era. However,teaching and learning are still traditional and teacher-centered. The atmosphere of teaching and learning becomes monotonous and cannot embrace all of its students. Students need something that can attract their intention to study, make them feel interesting, and not boring in the class. The teachers can use new media of teaching English, which is using interactive multimedia.

Multimedia is the exciting combination of computer hardware and software that allows integrating video, animation, effective presentations on an affordable desktop computer (Reddi and Mishra, 2003, p.3). Interactive multimedia is related to the digital culture, interactive design, new media, and human interactive design. Interactive multimedia can be implemented using a variety of applications that usetechnology, such as Adobe Flash CS6. 
Adobe Flash CS6 is a tool that allows powerful animations, interactive features, and other complex elements to be embedded in Web pages. Adobe FlashCS6 adds additional features to the Flash creator and player, including a programming language called ActionScript. ActionScript is used to create animation, such as to create action-oriented instruction (perform commands) and logic-oriented instruction (analyze problems before executing commands). Adobe Flash CS6is the potential application to make interactive multimedia to facilitate learning in the classroom. The main purpose is to increase students' curiosity and provide learning media that is not monotonous. Through interactive multimedia, teachers can increase students' insight and provide more motivation to learn English. The interactive multimedia is expected to be an alternative to help students learn English more enjoyable.

Learning English includes some skills, such as listening, writing, reading, and speaking. Students are expected to master those skills integratedly. In mastering English, students can start with reading, it helps develop other related skills like grammar and vocabulary. Reading more and widely is a critical component of improving students' speaking and writing abilities. Reading allows students to explore more topics they are interest, get new vocabulary, and expand their grammar. The more students read the more input their brain gets about how the English work.

Reading is a complex process of getting information and understanding written text. Reading is a process of thinking. Students are expected to know the meaning of vocabulary and understand the context of the text. In reading, there are many kinds of text, such as narrative, descriptive, recount, report, and procedure. In reading, students can start with reading the narrative text. Narrative text can improve students' ability to read and understand the story.

The narrative text is a text which tells a story or an account of sequences of events. The narrative text is commonly entertaining the audience. A narrative text also makes the students think about an issue, teach them a lesson, or excite their emotions. When they read a narrative text, they also learn about the feature of description in narrative text, such as the characters, the setting, the problem, and the solution. Through reading a narrative text, students will get more new vocabulary from the story. Narratives are stories about a person or agroup of people overcoming problems (Joyce and Feez, 2000, p.24).

The previous study that was similar to this research was conducted by Eamthanakul (2015). The title is A Development of Computer Assisted Instruction in English Subject of Third Level Primary Students Named Child's a Nice Day. From this study, the researcher found students' stereotypes towards English. They said that English is a difficult subject to study, which decreased their interest to study English. To help the students in studying English, the researcher developed Computer Assisted Instruction (CAI). The researcher used Adobe Flash CS6 as the main software to develop this CAI. The result showed that the computerassisted instruction had a good efficiency that could be used in the English class for the third of primary students.

Furthermore, the second previous study was conducted by Trisyagil (2020), the title is The Development of Flash-Based Media in Project-Based Learning for English Subject to Increase Students'Motivation and Achievement at Senior High School. From this development, the researcher found that the development of flash-based media 
has not been implemented in projectbased learning in the school. The research aimsto develop, to examine the appropriateness and the effectiveness of flash-based media at Senior High School. This development used the ADDIE model. The researcher developed the flash-based media using Adobe Flash CS6. The result of the research showed that the flash-based media increased students' motivation and achievement in the learning process. The research result supports the theories of technology learning, for the development of learning aids and media for English subject.

This research is similar to the previous study. The different thing is the researcher designed suitable interactive multimedia that will help the teacher to teach students in English, especially in reading narrative text. The researcher wants to make the teaching-learning process more fun and easier for students to understand the materials through some popular narrative stories, animation videos stories, adventure musicbackground, interesting pictures, interactive buttons, and fantasy adventuregame themes that make them enthusiasticto study English, especially reading the narrative text.

\section{METHODE}

In conducting this research, the researcher used developmental research as a method of research. According to Richey, Klein, and Nelson (2004, p.1099), the purpose of $R \& D$ is designing, developing, and evaluating instructional programs, processes, and products that must meet the criteria of internal consistency and effectiveness. The researcher focused on improving students' reading skills by using interactive multimedia for teaching narrative reading texts.

In doing developmental research, the researcher chose the ADDIE model as the research design. ADDIE design proposed by Branch (2009) consists of the Analysis phase, Design phase, Development phase, Implementation phase, and Evaluation phase.

This research was accomplished based on the following procedures:

Analysis

In this phase, the researcher held an interview session before conducted the need analysis. The researcher interviewed the tenth-grade English teacher to discuss the class situation, condition, students'English ability, and the materials preferences for the ideal interactive multimedia in teaching reading the narrative text in the class. Then, the researcher distributed a need analysis questionnaire to analyze students' targets, learning needs, and expectations toward the interactive multimedia.

\section{Design}

In this phase, the researcher started to design the interactive multimedia based on interview and questionnaire results. The data collected was used as the guideline to design and organize the learning objective and the tasks of the interactive multimedia. The researcher added some materials to complete the task. The material was based on the English textbook. The materials and tasks should be appropriate for students learning needs. After that, the researcher designed a flowchart to draw the flow and sequences of interactive multimedia. Then, the researcher designed the criteria that include the requirements of appropriate multimedia to do an internal evaluation in the development phase.

\section{Development}

In this phase, as the product developer, the researcher developed and organize the learning materials and the tasks of interactive multimedia. The materials from the English textbook were developed into the first draft of interactive multimedia. The researcher used three steps to develop interactive 
multimedia. The first step was adapting the materials such as texts, images, pictures, graphics, animation, and sound from the English textbook, resources books, and the internet. Second, the material developed into interactive multimedia using AdobeFlash CS6. The researcher used a programming language called ActionScript. ActionScript is a programming language used by Flash software to control objects or movies contained in Flash. Actionscript makes it easier to build an application or an animation that takes up a lot of frames and controls it. Actionscript can also be used in-game creation in Flash. (Sutopo, 2003, p.11). The use of ActionScript in developing the interactive multimedia was to create the site navigation system, add the interactivity with users, such as button, movie clip, or text input, and alsocreate a dynamic application. And the last, the researcher did an internal evaluation.

\section{Implementation}

In this phase, interactive multimedia has been created into a complete app and has been tested by the English teacher and the multimedia expert. After that, the interactive multimedia will be implemented by the English teacher in the class.

\section{Evaluation}

In this phase, the researcher evaluated to get feedback toward interactive multimedia by giving a questionnaire of expert judgments to the English teacher and the multimedia expert. Afterward, the results of the product assessment used as a reference for the researcher to fix the final draft of the interactive multimedia.

The subjects of this research were an English teacher of MAN 2 Pontianak, the tenth-grade students of MAN 2 Pontianak, and theexpert judgments in the technology field. The researcher interviewed the teacher andgave the questionnaire to students tocomplete the analysis phase of theADDIE model through the online googleform. For the product assessment, theresearcher gave the expert judgmentquestionnaire to Siti S. Pd. and Drs.Zainal, M. A. as the technology expert.

The data of this research was collected in a qualitative form. The data was collected through the online google form. The researcher used two techniques to obtain the data, they are interview and survey. First, the researcher interviewed the English teacher of grade ten. Second, the researcher gave a questionnaire to the students and a questionnaire of expert judgment to the English teacher and the technology expert.

\section{The technique of Data Analysis}

Analyzing the qualitative data, theresearcher took the data that has been obtained through interview and questionnaires. Then the researcher analyzed the result in a descriptive way. The result of the data was written in the form of interview transcripts and questionnaires. After collecting the data, the next step of this research was analyzing the data that has been obtained from the data collection. The researcher used descriptive analysis to analyze thosedata. The researcher analyzed the teacherresponses from the interview, the student's answers in the questionnaire, and the results of product assessment from expert judgments. After that, the researcher described those data in the form of descriptive analysis.

The result of the data converted to descriptive analysis in terms of its goodness. The indicator used to measure the Mean (X), The "Mean" was calculated by using the formula of data conversion by Sudijono (2003) below:

Where:

$$
\mathrm{Mn}=\frac{\sum f X}{N}
$$

$$
\begin{aligned}
\mathrm{Mn} & =\text { mean } \\
\sum_{N} f X & =\text { number of scores } \\
& =\text { number of cases }
\end{aligned}
$$


The result of the data will be converted to descriptive analysis in terms of its goodness. The researcher was used a scale to find the agreement towards the appropriateness to the interactive multimedia. Data from the expert judgment questionnaire used Likert-Scale as the measurement, the indication of the responses to the statement was measured by score. There were 5 points for Strongly Agree (SA), 4 points for Agree (A), 3 points for Undecided (U), 2 points for Disagree (DA), and 1 point for Strongly Disagree (SD).

The statistical data of the expert judgment questionnaire was proposed by Sudijono (2003, p.335).

Table 1. Data Conversion Table displays the result of the mean value was appropriate or less appropriate.

Table 1. Data Conversion Table

\begin{tabular}{ccc} 
Scale & Interval & Categories \\
\hline 1 & $1<\mathrm{X} \leq 1.80$ & Very bad \\
\hline 2 & $1.81<\mathrm{X} \leq 2.60$ & Bad \\
\hline 3 & $2.61<\mathrm{X} \leq 3.40$ & Fair \\
\hline 4 & $3.41<\mathrm{X} \leq 4.20$ & Good \\
\hline 5 & $4.21<\mathrm{X} \leq 5$ & Very Good \\
\hline
\end{tabular}

\section{RESULT AND DISCUSSION Result}

The researcher used the ADDIE model as guidance to develop the interactive multimedia to teach the reading narrative text. The analysis phase plays an important role to design the appropriate product. It became a consideration for the researcher to design interactive multimedia based on students' needs and target needs. By designing the interactive multimedia (English Gain App) the researcher aims to help the English teacher to teach reading narrative text to the tenth-grade students by using the interesting, interactive, and fun interactive multimedia application.

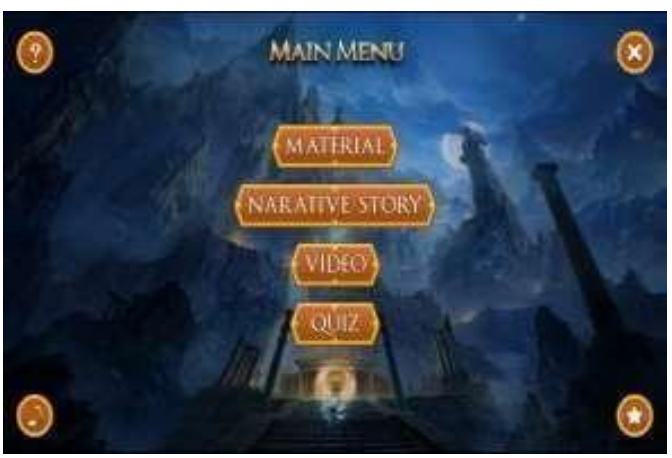

Figure 1: Pictures of the interactive multimedia

Interactive multimedia was designed based on the results of students' questionnaires and teacher's interviews. The students wanted interesting and motivating background, readable font size, commonly used font, back sound, and an easy find button. The use of interesting pictures, animation videos, game themes, and interactive quizz will improve the students' motivation in learning English.

In developing the interactive multimedia, the researcher followed the six key factors that should be considered in choosing interactive multimedia (Indriana, 2011, p.28). The first was compliance with teaching purposes. Based on the questionnaire result, students want to master many vocabularies and learn good pronunciation. The second was compliance with the materials that will be taught, the researcher designed unit 2 and unit 3, Animation Story and video that contains 20 famous narrative stories and animation video stories with subtitles so that the students will learn the new vocabulary and the right pronunciation. In quiz 1 and 2, the students will do a vocabulary and pronunciation test. In quiz 3, they will do a grammar test. In quiz 4, they will do a multiple-choice test. The third was compliance with supporting facilities, environmental condition, and time. Based on the questionnaire result, the students expect the interactive media that enable them to 
learn English whenever and wherever they wanted (self-learner). At school, the class provide in-focus at class to support the interactive multimedia, the teacher explains the materials. At home, they can re-study the interactive multimedia (desktop application) at their laptop. The fourth was compliance with the characteristics of the students. The students were typical of self-learners that like something that relate to technology, such as game and social media. They can operate it at their own laptop at home. It trains them to self-monitor and selfaccess to their progress. The fifth was compliance with the students' learning style, the interactive multimedia introduce a variety of texts, images, audios, and videos that match different students learning styles and preferences, such as visual, auditory, or kinesthetic. The sixth was compliance with the theory used.

The interactive multimedia is expected to motivate students to learn English more enthusiastically, enjoyable, learning interactively, flexible with students' time, and accommodates the individual learning style. The materials about narrative text included legend, fairy tale, fable, and folktale story. The researcher provided famous narrative stories and animation videos with subtitles. The materials were from the internet and youtube. The activities were divided into four sections: pronunciation, vocabulary, grammar, and text type. In the pronunciation and vocabulary section, students focus more on checking the correct pronunciation, mastering vocabulary, and matching the words with their meaning. Then, in the grammar section, complete the blank space, change verb 1 into verb 2 . For the text type section, they will answer multiple-choice questions.

\section{Discussion}

The product of the interactive multimedia was in the form of an application. Both the teacher and the students use a computer or laptop to operate the program, either in the class or self-learning outside the school. For effective used, the English teacher should accompany and explain to students about main materials first. Then, for better understanding, students can do selflearning at home considered their own learning style.

The first draft of the interactive multimedia was evaluated by the English teacher and the multimedia expert. The result of product assessments was used to revise and develop the final product of interactive multimedia. Based on the result of the expert judgment questionnaire both from the teacher and the multimedia expert, the researcher needed to do some revise. From the results, it shows that the interactive multimedia quality belongs tothe "very good" category with $4.21<\mathrm{X} \leq 5$. It can be concluded that the interactive multimedia is effective and appropriate to implement in the class by the English teacher.

\section{CONCLUSION AND SUGGESTION Conclusion}

The interactive multimedia was designed based on the result of the students' questionnaires and teacher's interviews. In terms of media, the researcher designed the interactive multimedia based on students' learning needs and target needs. The students wanted interesting and motivating background, readable font size, commonly used font, back sound, and easy to find button, the use of interesting pictures, animation videos, game themes, and interactive quiz may improve the students' motivation inlearning English. The researcher designed units 1,2 , and unit 3, The Materials of narrative text, AnimationStory, and video that contains 20 famous narrative stories and animation video stories with subtitles so that the students can learnthe new vocabulary and 
the right pronunciation. In quiz one and two, the students will do a vocabulary and pronunciation test. The researcher provided famous narrative stories and animation videos with subtitles. The materials were from the internet and youtube. The activities were divided into four sections: pronunciation, vocabulary, grammar, and text type. The final design can be seen in Appendix 5.

Based on the research findings and the data analysis, it can be concluded that Interactive multimedia is effective and appropriate to teach reading narrative text of the tenth-grade students in MAN 2 Pontianak. It was proved by the result of questionnaires of expert judgment. Based on the result of expert judgment questionnaires both from the teacher and the multimedia expert, it is said that the interactive multimedia quality belongs to the "very good" category with $4.21<\mathrm{X}$ $\leq 5$.

\section{Suggestions}

Several suggestions were proposed to the teacher, the students, and the other researchers, those are presented as follows: To the teacher, the interactive media will help for English teacher to teach the reading narrative text as additional material in the class or selflearning outside the class. This interactive multimedia is expected to inspire and motivate the teachers to be more creative and innovative in developing interesting and effective media to teach English. The teacher should consider the target needs and the learning needs of the students. To the students, the result of this study is expected to develop students reading activities with interactive multimedia that will improve their reading skills so they will be more motivated in learning English. Therefore, students should use this interactive multimedia optimally by learning the materials, reading the narrative text stories, watching animation videos, and finishing the quiz. For the further researcher, in developing this interactive multimedia, the researcher considered the students' needs and target needs. Thematerials, design, and quiz are based on their expectation on the questionnaire. The result of this study is expected to be a reference for other researchers to create interactive multimedia with upgraded quality, various interested and fun activities, and good materials.

\section{BIBLIOGRAPHY}

Creswell, W, J. (2009). Research Design (Third Edition): Qualitative, Quantitative, and Mix Methods Approaches. California: Sage Publication, Inc.

Creswell, W, J. (2012). Educational Research: planning, conducting, evaluating quantitative and qualitative research. Boston: Pearson Education.

Eamthanakul, B. (2015). ADevelopment of Computer Assisted Instruction in English Subject of Third Level Primary Students Named Child's a Nice Day. Bangkok: Suan Sunandha Rajabhat University.

Eck, J, D. (2018). Introduction to Computer Graphics. New York: Hobart and William Smith Colleges.

Indriana, D. (2011). Ragam Alat Bantu Media Pengajaran. Yogyakarta: Diva Press.

Joyce, H., \& Feez, S. (2000). Writing Skills: Narrative and NonFiction Text Types.

Reddi, V, U., \& Mishra, S. (2003). Educational Multimedia: A Handbook for Teacher Developers. New Delhi. CEMCA. Richey, R, C., Klein, J., \& Nelson,

Sudijono, A. (2003). Pengantar Evaluasi Pendidikan. PT. Raja GrafindoPersada: Jakarta.

Sutopo, H, A. (2003). Multimedia Interaktif dengan Flash. 
Yogyakarta: Graha Ilmu.

Trisyagil. (2020). The Development of

Flash-Based Media in Project

Based Learning for English

Subject to Increase Students'

Motivation and Achievement at

Senior High School. Semarang:

Universitas Negeri Semarang.
W. (2004). Developmental Research studies of Instructional Design and Development. In D. Jonassen (Ed). Handbook of Research for Educational Communications and Technology (2nd ed). Mahwah, NJ: Lawrence Erlbaum Associates, Inc. 